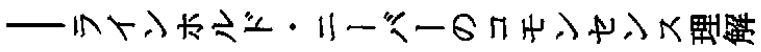

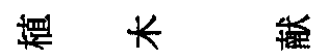

\title{
The Circular Relation between Faith and Experience: Reinhold Niebuhr's Theological Understanding of Common Sense
}

\section{Ken Ueki}

This thesis mainly focuses on Reinhold Niebuhr's "common sense." He indicates that common sense or experience, which is distinguished from reason, cooperates with revelation or faith for the basis of freedom and publicness in "the circular relation between faith and experience." The former studies have barely paid attention to common sense as theological subject. It, however, should be examine in the studies of the Holy Spirit. This thesis aims to answer the following question by showing Niebuhr's understanding of common sense in the context of sanctification: how can Christianity live together with secular society or other religions without losing its uniqueness? "The circular relation" as sanctification allows us to have a spiritual maturity of common sense called "religious humility" which opens up Christianity not only to God but others who do not share religious presupposition. 


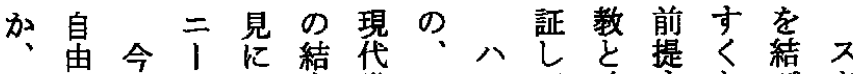

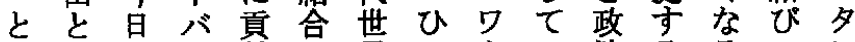
い公私了献に界い!い治るるるン

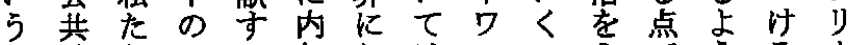
も性ちこる包拈はスこミ゙らうる

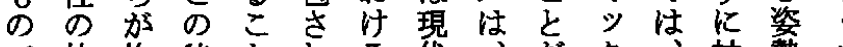
で枠抱特とれる代れ神勢 あ組え留にて問キ信とス学を学り

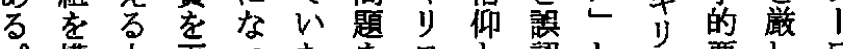

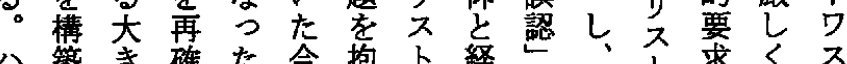
八築き確た今抱卜経路、令求く不 ワ等な認の白え教験さア教を紏は 1 る 課しで的た䚮とせメ教自弾こ ス と は加一の。性の弇本の就合い コでつ今本の結根に合教し占らに ンきは日論再合本三で会ろうで対

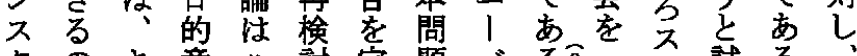
タ の キ意分討 完題バ る。る テか、少味 ワ に全で | イで卜論りを解る思少派汕答 又き教し ス開消。想思にと气え 加い加る の

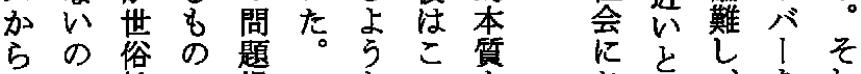
三加社で提二と六を㧤断方をれ

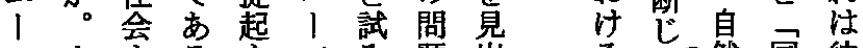
バままるをバみ題出るるる然同彼

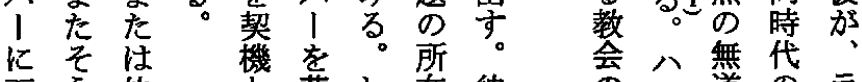

至 5 他 葬し在彼草ワ道のラ

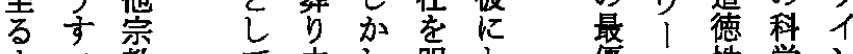
ま六教て去し明と優り性学ン

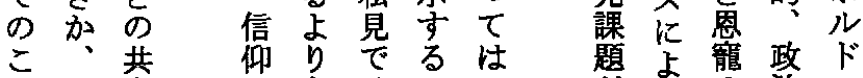

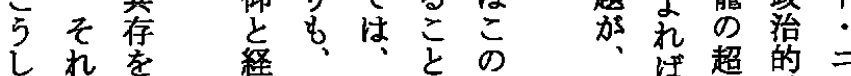

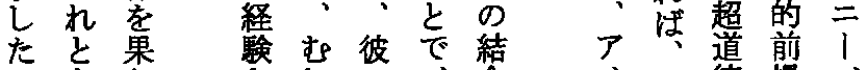

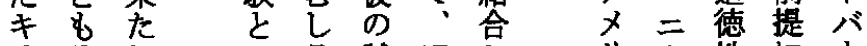

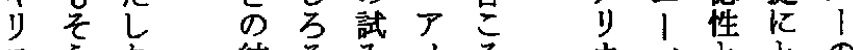

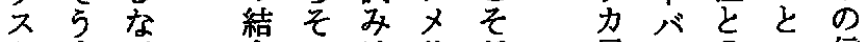
卜す加 合のは加 民1信

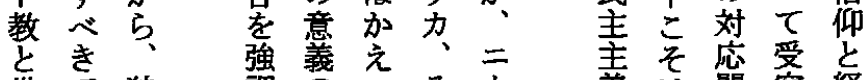
世它独調の我っそ義は関容経

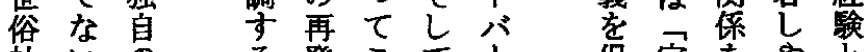
社以方発こて 


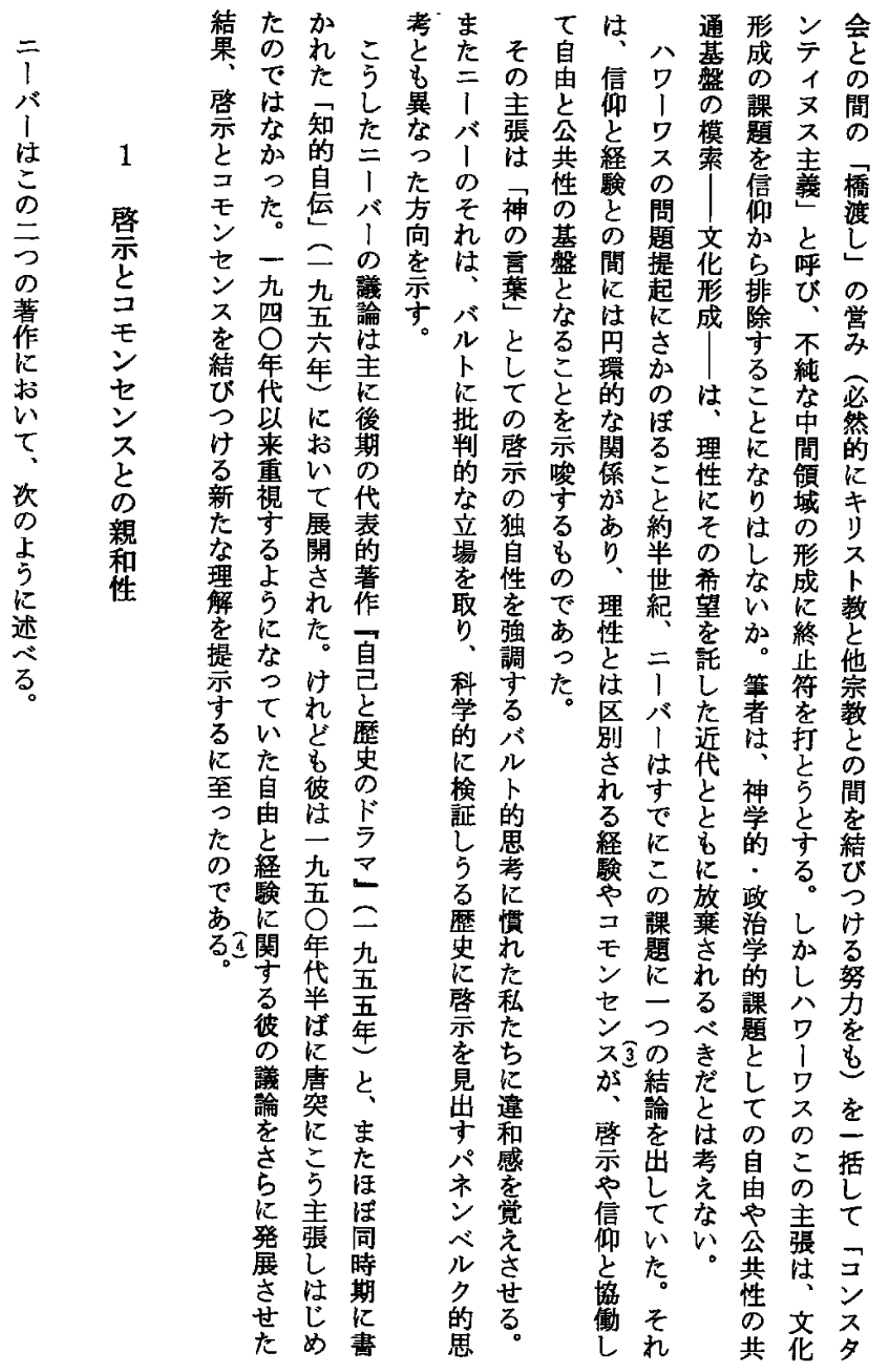


挑た漟々存人持わ

をち過わ在がたた は器たし表せし 事正としな面るの 奉し L を以的方護 いてかのに法教

色とはりではは論

づ思たたあ経な的

けわらてる唤いな

は注た。加追

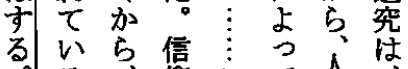

し

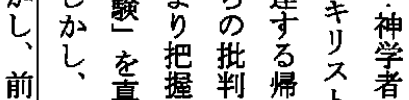

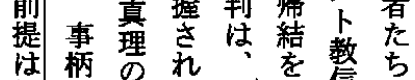

経杜究た 信支信

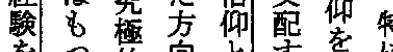

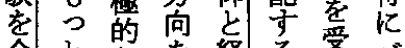

全面複決 每

的雑 定

統あ

御 る な提 の 験 加加

济方空

な向之経的等

いてををに験 な

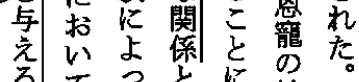

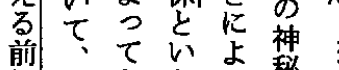

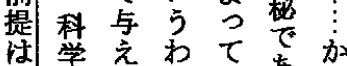

脑学省占 た

経た者らし仰るるら

験ちた の学市の

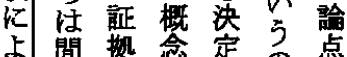

よ間 贽 念定 の 点

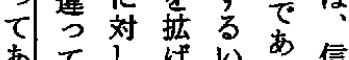

あて し

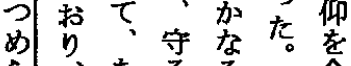

ら神る る る 方信合

应学種方法仰的

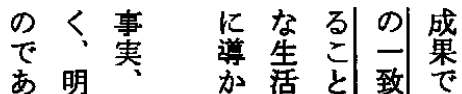

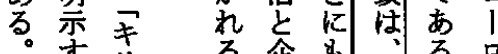

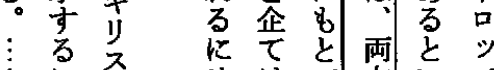

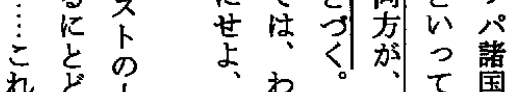

加ま士字 われわ人よ自

キる架

j \& 架

スの

卜な教 な

信で挛

仰市

にる

よキき

て リ

明

示卜 考

丸孝 え

る仰泉

状にた

況上場

て 2 合

あて の

万互明 状

示 況

さ

机橍

名秋

況 真

は理

常老

経 上

験 ら

に押

52

32

確 る

認 \&

む

れで

るな
わ わ れ

は理の語引。

そ解 個を

れを々满わ

を超のたれ

受充生しわ罂

讨た命て机量

入神吕以は曲

る計こさでキ

こ画の主にり

と の 断 ざ

中片妾常卜

学で性 な識教

ん究にテ の の

で極 よ 11 知 洞

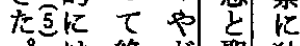

傍䝶稳 だ聖 独

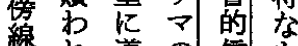

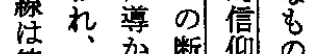

箻完 れ 片 仰 の

以さに徴る

市机せ韭的と

同い小結洞 5

るあ的察京

とる性 と り

い筫 の

5 は安二位

信絥

のわに見な

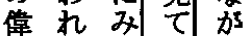

大のとをま

な断めた経

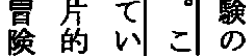

れのれ物ろ識

れの、るすは

者成 る的特 あ 


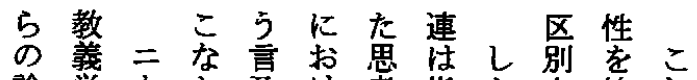
論学了吕是讨考指加さ持れ

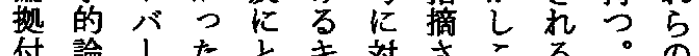
付論当获 が付デでまス心つま立信角 模汗壬あっトプつでし仰は

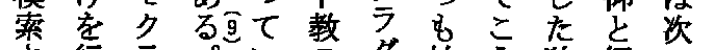

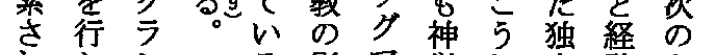
机势影学学自験占

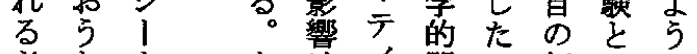
必をな亲告問三価のに

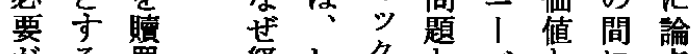
怔る罪経しクとバに点 あ優の験ばなし、領はを りれ制队し開ての域円整 なた度コ社吕十経を環理 が議之壬難杂分験持的で

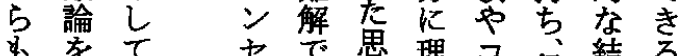

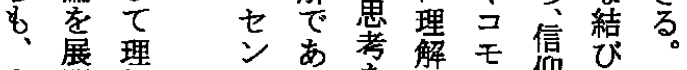

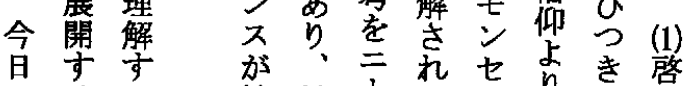
八るる 神神 ワ。学学バこス寻あと 1 経 1 的 的 1 な ワ験キにに架か強气、モ スやン裹裏重つ調セ相ン

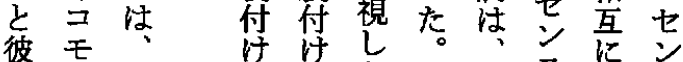

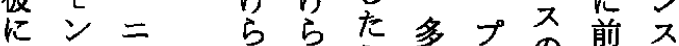

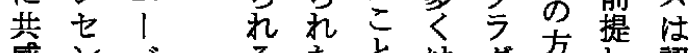
感ンバるたとはグ方し認 すス の人にス架市識 る ル調治 漖こンズ本 (3) 奉 ᄀ六的 点説 から社に电方文全ン㸝

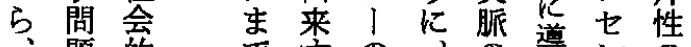
二題的 です 1、察のラグに文は認 バ同ッ唯でグマ包唯に 1様卜深あ文摄架示お はのメるテ的さ西信い

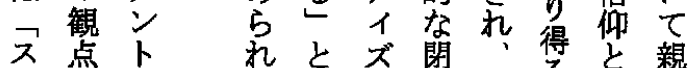
ト加の て

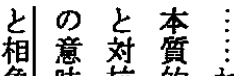

争味执的わ 与寺にれ こ認る偶わ 々めた像れ なぬ整注 知讨に挷 でせ 神的人 る 特異 実な別の品

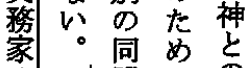
ここ盟にの よ) あ 用 交 <主心方 練 5 張 50

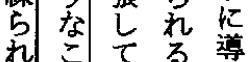

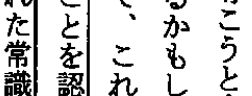
喊䛌杂机主 方な用なる 加就信 キ惒方 光真 全基 れ と 者科なを加 学知者。認 恵弇わな

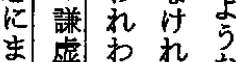
さ虔わ礼 る息流な 纪分宗な礼 な貝的。择 る 的㹥 人 で他售は式 あ因正義 当長机方 な目歴 
のアでなじいへ人的

みプ他あかく。の諭 理方るっ、予過体点

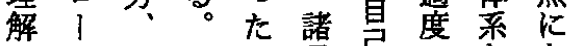
でチ = きを 1

る歴 バ

の史 !

で的加

あ現 コ

る。実モ

自向 セ

然きン

で 合

あ合を

机基重

理本的 ᄂ

性な晸

あ勢宗

杂窅

人な䙷親

間 䇆和

を加

何方考

らで袁

加蓑張

の る13

系 の

に人は

結間

び体

つ系

け \&

よのは

らはな

守副く

万経

努 歴 験

力史 $反$

注合的占

事境㷌

実の納

老中的

誤でな

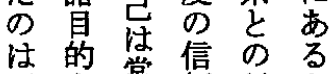

明壱党頼対去

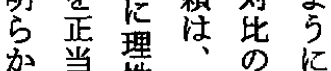

要等主㡷脈二

る责䒧纱

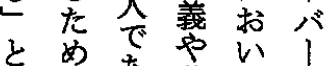

彼长共飞加

註子?産で綮

述理?圭要示

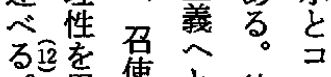

。角焦卢彼毛

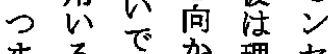

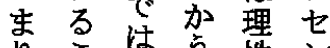

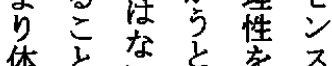

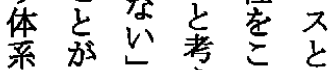

ので。竞ら市

形きそ主親

成危。和

でのた理な性

柇でめ性体を

要自委

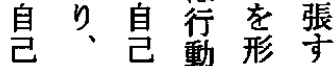

の理性㠿成る

自性自等

㕣面標多性

と人等程

矮名の判の普

御の諸断と遍

钦等等的

果望的る

厄店自理抽

乙野判宊解象

得忍断向车的

な㨁る

心制方县加合

と限厄县理

考称纪飞的

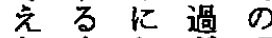

去分芦理演

の加同な性繹
㤎集性全文以
二でわ 的 バるるれる 義 l。必と根 ズに 神こ要毛樾公よ 学の肪三をとっ のよあ 1 失のて 聖 うるバっ間彼 化なと I たのの 理問筆の\&結 キ 解題者強の合り を提は調と品

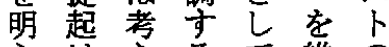
らは党るて維の 吕義る。経扱持証

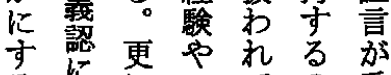
るににコての妥 こ偏踏モWに势 にた込セ馀敗せ

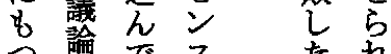
つ論で不たれ な嘿靠注解た る露等前秎め だ諞る述さ ろ婴なな れ た注点 。然 議そ考 こ犠

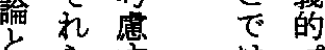

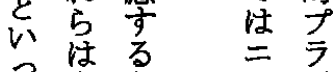
た瑟なる゙

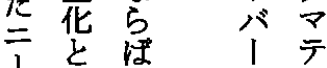
心の のイ バ関や試 ズ 理連は㕕

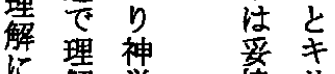

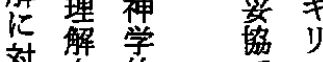
対蟹学的妿 反杂問 あ

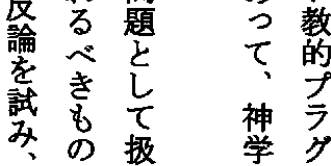


たる越的する他含柳う理べす理い来こ㠰る

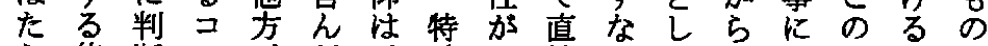
多ら能断壬、だ、殊明接わてでおよ加で

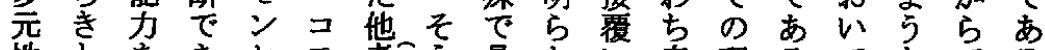

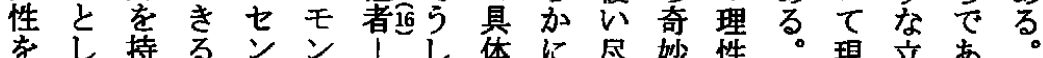

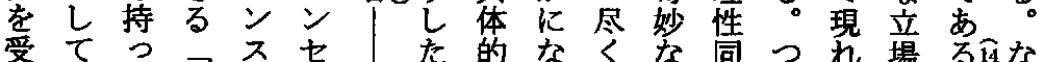
容のた䨘のンを公なるす言㴍まる热る。ぜ

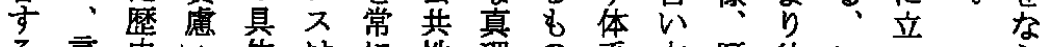

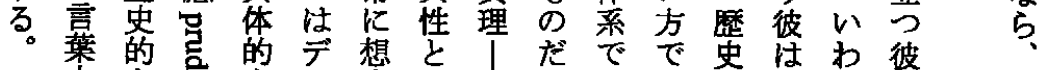

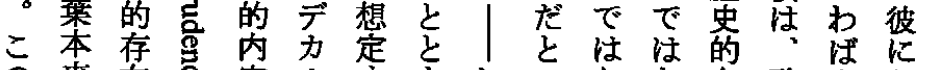

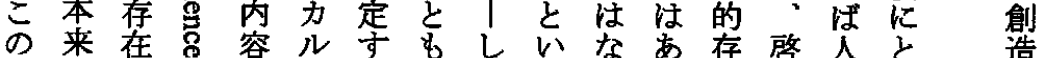

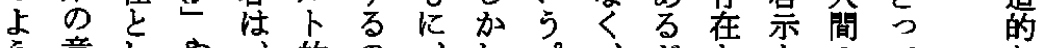
5 意し や 的 の な味て公日理で内㤵前、し第生は能 総で人共常性あ部る示提二て向方 体の間心世にるに公はに!の原意壁 的艺を、界含。取共原と心゙人理味系

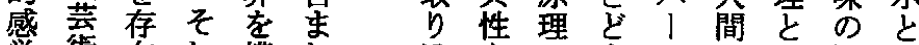

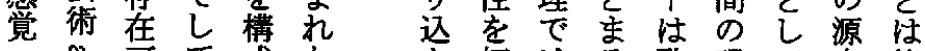

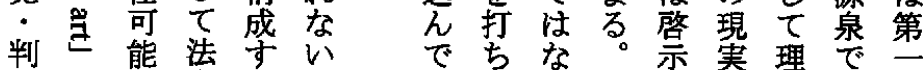
断なに賢る蓋 に どす 慮17儀 然 はでる。礼 性 ああ過や海 よる留記去知お り。憶を識 け 優こヨ確でる れれ音は総 たら宁な体

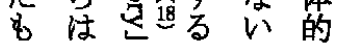
の対。こ。感 そ立別究䙮賞 うるの批な判 で自も判諸断 な的のを事で いやを可象あ も価結能加る の値びにら。 齐存合产 具 あ在せま的バ るを、た行 は た 前 調 時 動 め提和間悹問 個る导を超合 題

旁 壊 的 な し立くそを理解あ原熋 ま抽し演解しる的市市 5 る象て繹を、䚮で耐 真性個的加そ、は方 と理占に々でえこ信な の丁抵のは方仰い含 出抗経なてら者。ん 来で势驗く困体に㤵だ

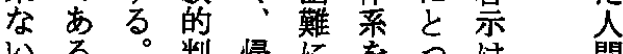
いる。判帰にをっは間

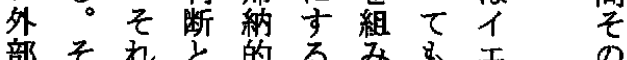

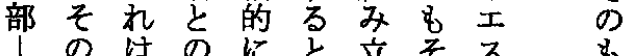
た独間捉考宁の! の 神め自接ええて意キ や、艺的るるい味り自 二多な。标不 異 様相㤵演常卜 繹 るに信に間険経 登暞字字 仰お的に験想た架热

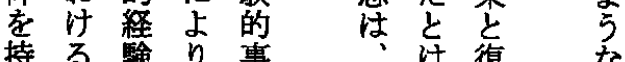

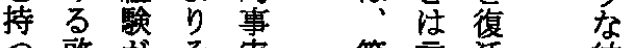
己㹈加 そ実第言活 他示出の者一充 原な出 


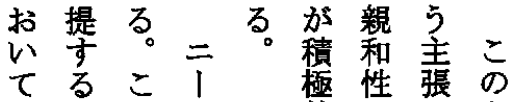

一かのバ的とはよ

般方 1 ない一う

的で張は論ら応に

にあを冒拠この自

観る批頭をと説己

察。判の持に得の

しし的引たな方外

うかに角なりを部

るし見文 $心$ 持性

事それ中常つ

実ればに ら識し他

し無論見 あ知加

息理 ら智し。

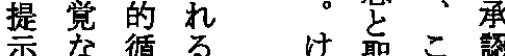

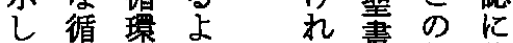

た環論 $う$ ど畫親焦

の論でに它信和点

だであら親仰性を

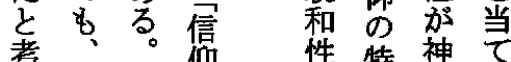

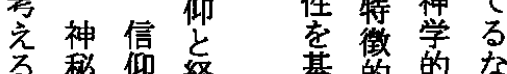

る秘仰経基的的な

へ主は験碄ななら

き爔経と哭洞根恄

で的験のけ察扰

あなを間る管を確

る逃前の 神の持加

。避提 円 学二たに

例で势環 的致な啓

えるる的な整い示

ばなが関論はなと

バ、、係 拠十ら

ル。経僁驾分代モ

卜信 験と

の仰は心

神炎舞䇋

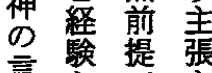

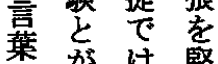

㤎唯㹂

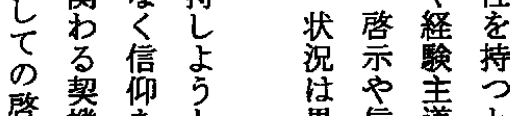

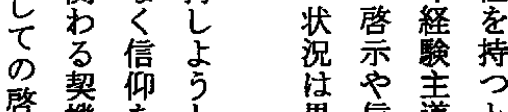

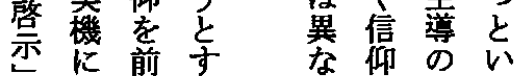

対照 部。二罪全 をとこ1さか なしのバを生 寸 $\tau$ 点 I 前 し とのにに提る 彼他おおとと は者いけし同 考のてるた時 え存両啓上に のに性と、蓄 でよ親コ加積 あり和モまと る、性ンん成 自をセの熟 ら持ンでが 考不求 限、はるめ 界協と程ら 了㗢安度れ け夺保のる るる、共

点可私合飞 で能厄体元 体を加確共 系持支立同 につ配 せ 体 上や久 形 两操と成 て者作守纪 全性でる扬 体、努い

を自な务

覆由心性 究外竟。

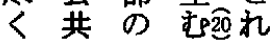
辛性存。” 5 क 在 創感 出賞

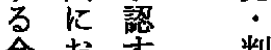
畣抒变判 丟点注

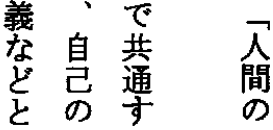


でいれれ る。之全力味れ学の示分自こ

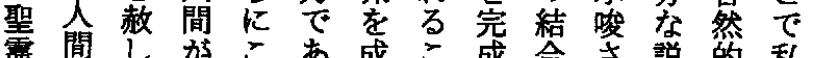
要㤎し 完 こ劣成こ成 合さ説的私 た真で完のる恩る就とで点れ明资た

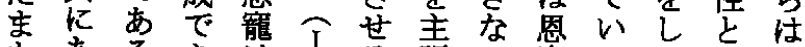

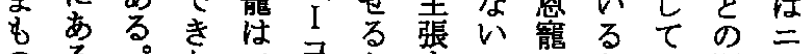

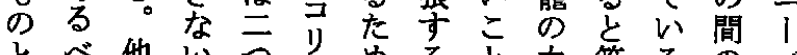

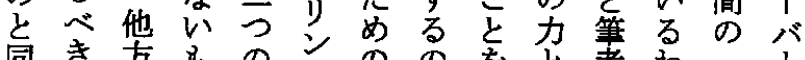

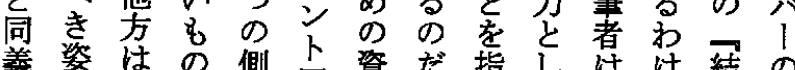

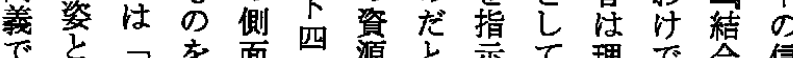
あ゙な人神面方源亡亦説理で合信 るる間驾持 と立 5 完つ

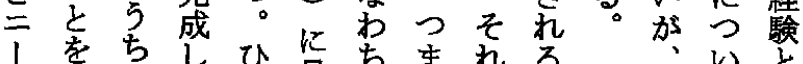
バ可にしをを見ち市れる。

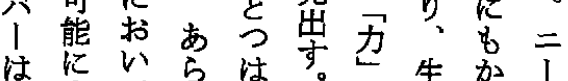

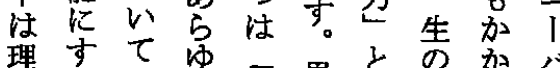

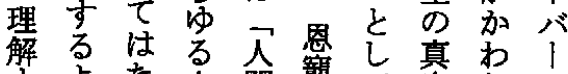

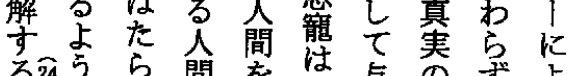

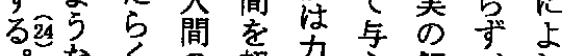

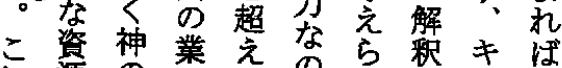

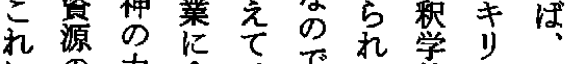
にのカ含は告る的不キ

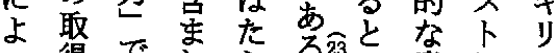

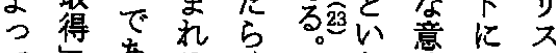

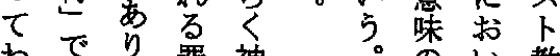
わでり、罪神 れあっのの わる。要 力 れっ間素 加こ加をで 自れ自神あ 己は らが 息人間 \& 克 神 に間の L の 囚内でて 性 わ内 市れ れ在なされ い る 状の源いしい 態需角粼っ

。の以教 彼提ての は示口啓 そ智示 の蔠恵は 根わ县 拠ると人 をの同間 てで 時 が 神はに罪 のなつの 国く召た は、こめ 言同肪人 葉 時人生 でに間 の は に真 なそ每其
₹

の考間

論 盧の

拠 L 結

一、合

九な点

四以心

年々 に

に批目

出判守

版守 る

さる望必

年

た確 㖣

人架京

間彼。

の の

本批 ワ

性判 !

之す

運るス

命とは

标二

第 り、1

巻 $=1$

の 1 加

中゙バ 恩
あなンは

ばル第

倍 ク -

㑡に次

と打大

経以戦

験 て 前

亡 छ 後

間了 社

にア゚ 会

円状

環 才況

的 者

関にら

綮経

見舀的験

采光判

ハ ス

の 教 関

神なな゙

的伝な

䚺南

教 主琵 方

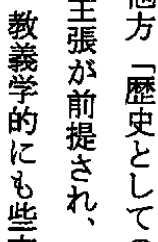

末 肯 の

問 定 示

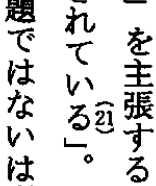

ずそパ 


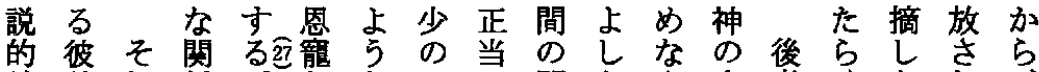

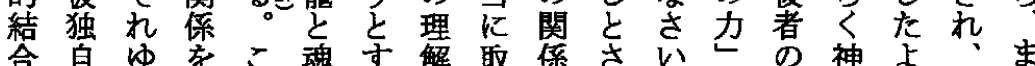

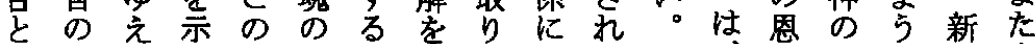
し聖己そょ自罪持报関るあ、巃力にしナ

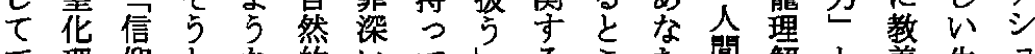
で理仰とな的いててるこた間解と義生

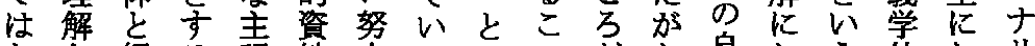
なと経る張性力る三のだた自拉う的おり 乙駼。をを。主加の是い対にけズ て通の通そ心張ら5意て比はる台 聖提のし間しれ门こでち志、聖自な 华 等間 とさの

余田

て 環

論 $い$ 的

こる 関

る䙷係

亭住

神茂神

の 妥

国 当 恩

形 籠

成あの

ある力

神。亮

学引

根 态

拠、答

と婜 と

乞 霞し

たをて

の 驾 の

でむ人

あ両間

る者の

$\tau$ の

彼は市は学

義炛宊 と

諗の の

は結、有ら

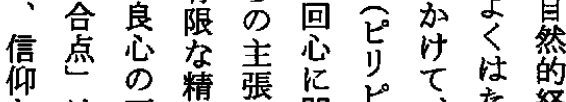

之注不神神関

た 経

経、安神聖禁三

そ $ら$ 験

験罪逃自書る

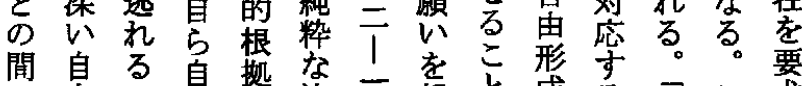

と 問 再 無

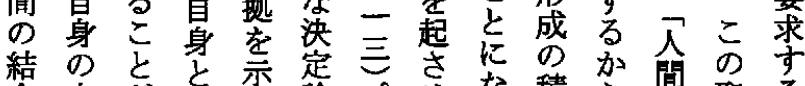

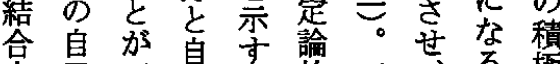
点莡で

を満き号で解ウか方台的

示足なむ市秎口占意

し、摇以の哥や純示現あで味

見当と居粋しにる。

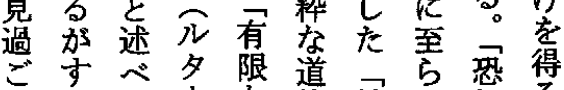

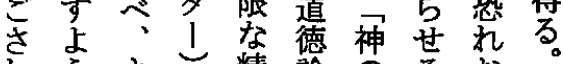

れらネ精論のる挍。

てな范と神的恩のの人

き結テしは解罷はの間

た合 $て て$ 自釈と神いの

信 結 胄

禹

仰び

とつ責 者しな

の 5

人でて

間て観 5 有良の分に

にい点の限、自ての就

経き任本る吕生性複由、救心

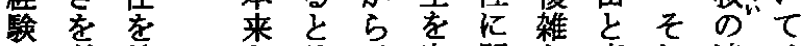

と单結

加なび

関るつ

あ彼見完関な責れ達は

る任て成し事任成た

わ逆け

複説 \&さて実と神にら

ら 聖る

で超霊 こ る25

はた的

た

点

神 議

の 論 加

力活 号

と 既 人

沉格

間齐破

の ス 壊

5 : 要

万夕当

k $1 こ$

掠立

いンな

七 く

注指 解 


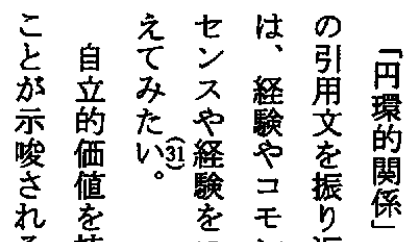

る持兰返江

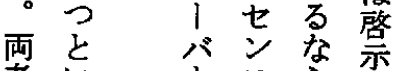

者少近年

茂与 はに台

辠息枠壬

的注音組経 ン

に偠繁导

势最值え引不

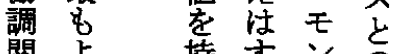

関よ持すンの

俰いる方関

入桨导方文集

るに皇衣密

わ拉卆杂㫃

でて捉は管䋨

は㹈学前信つ

示提仰

そ学学に枠る

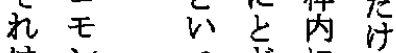

はンっぼにで

個セて炰は

人䒔占る括な

内注。方枟

面一本で尽両

に 致節 あく者

お亦でるしに

いる汇。間

てを こ

もの の のい距

その自意な離

5 立味いを

で時性で。す

あに対流置

ᄂ 辛 $心 a や 。$

教る 劣 そ信冒
人いる箻を追な八る

対气1求加口機

すとバ考守つ视

るはするるた

3 否はる。的光

リめ当文はて

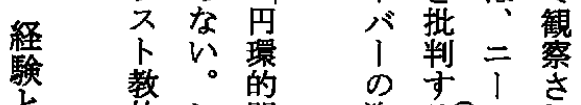

的し関姿る28 れ れ

真加集注。门た

モ理し货け加事

ンの聖をれ義実

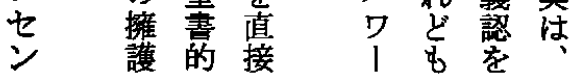

スに教䓔前強こ

のな説羲 ス述調こ

自るを学の年ず

立 と的批よる単

的翢経に判うあな

価張験体になまる

值

し の采 は聖り事

弁請宁密华䒠

証実る记義り号

論 乞こ 論 ス 聖

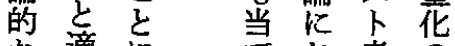

な適に光抒者の

立磨は心い現

場る简 るて生実

ら老な人拉な

論之持 心間けっ

ににた

る独自成の

姿よ

勢元た のと市

宗閚め、霊責哥能。

尔接議性玵售性

に的論理を

と論㤎を想考

論見模的え

ま学堂䅨る

るるに香発余

のとく揮地

で㤎な 导さ索

る30睍つ だる。 
の 独こ な

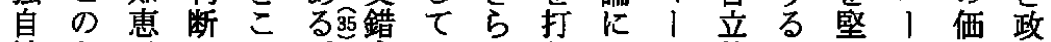

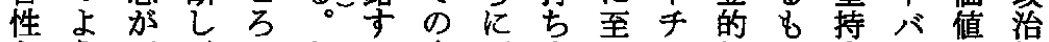
とら不、のとる多別立っル価のす、社 同に可自っれ市元のてたら值とるは狭会

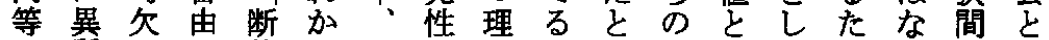

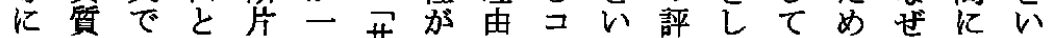
認なあ公的っ共あとモう価て理でこおっ

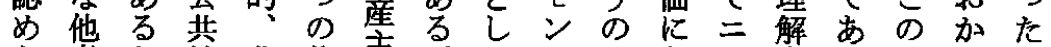

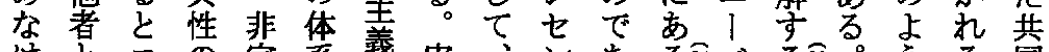

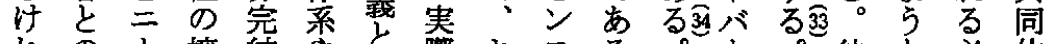
れの 1 擁結や等キスる。必体 ば共バ護的プのさリがっがこ蛙自要間

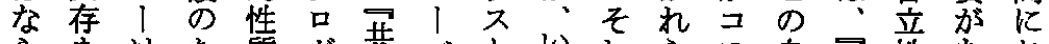

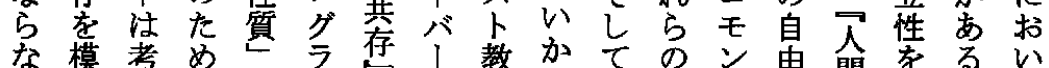

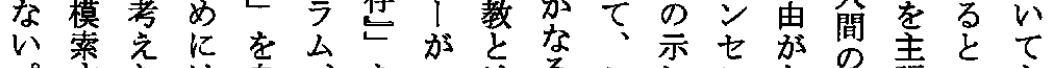

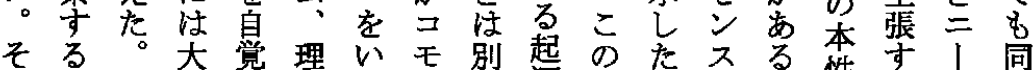
のコこ盟し念加ンの源事政を加性る心゙様 たモのななにた洒の実治強ら渾の、知

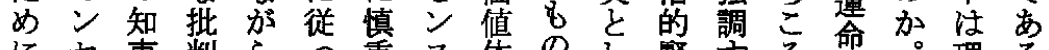

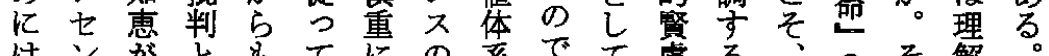

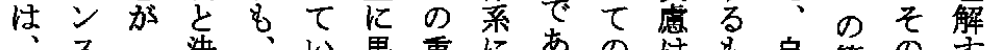
真や

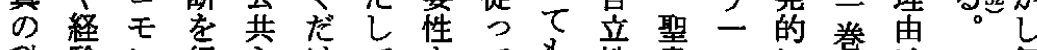
科験ン行心汀てをてを性書つに学 は個 学的セいをでい論動尊を的の神お比人 者判ン、持はくじく重尊伀契にい較にの

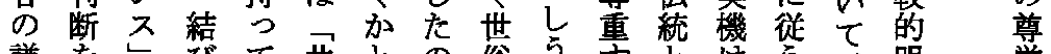
謙をし怘て 共との 俗 5 す 虚尊で難、存いは社るる䄈自人確や

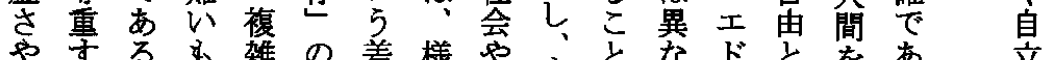

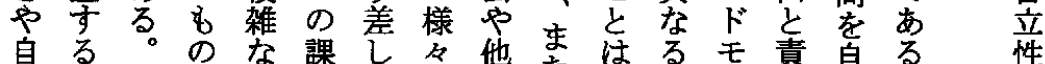

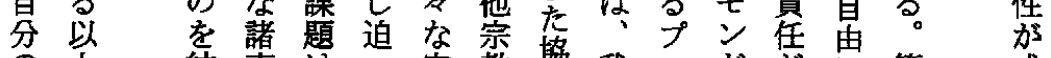

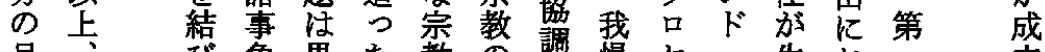

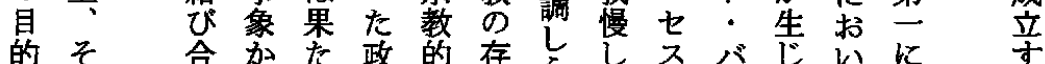

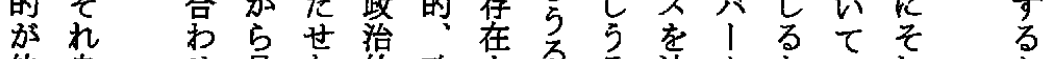

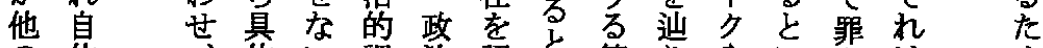

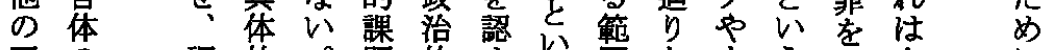
正 の 調的。題的め泪なウ 5 犯人 な当独 和 行

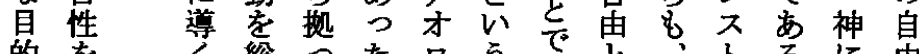

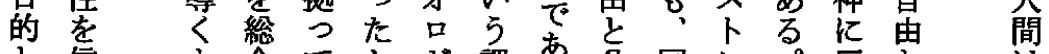

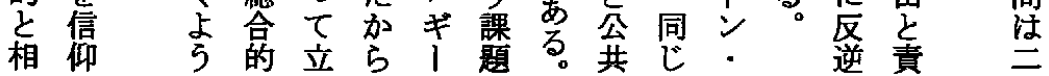




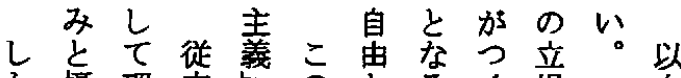
加摄 理来范 し 理解、のよ公。ら立モの 一吉二力 5 共確れ主ンよ 九にれ、点に性がるす 六見てバの二創にとにンに 九出き I 変 I出信、実ス = 年さたの化バの仰そ践は社 ベれて が基とれし教バ 卜てそり明に磒主はう義! ナきた斿て 戦年教にるて観ま系モ 争つの現な信提ン察たのン のま神実つ仰示ス可示中 是り学主てとしは能人にン 非、的義くさた常な間完ス

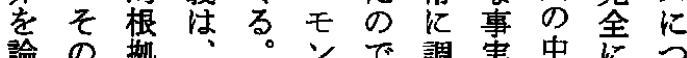

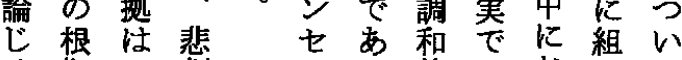
る 起省 1 は神的 $ン キ の な$ 夕リ憐歴

ビス史 ュトみに 1 論 の

で的保 以

の 側 証

二面と力

1 加啓の ハら 示均

1 論 だ 衡

の し

発らるよ

言れキつ

はるリて

女

異の卜対

なでの的

るあ福 正

側つ音義

面た放萶

唆 守

る 神 学

の

惠と スる。的は版み文 の 係くて安討 関江、はれ立 係 あ聖たてる をる花らはと 聖わのくいく 华 け現神なそ ので実のいれ 問は夌力。杭 題なし単 と

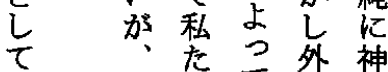
理 =ちて部学 解 1 信性的 寸 バ 具仰主 る 体 $\sum_{x 又}$ 他根 之的経 著 放 歴な 験 性 彼史判と立 の 丙断閶承 にと間認い キ お実にと主 リ け践用以费

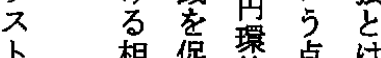
教 相 促的点 ま 4 少抙竧

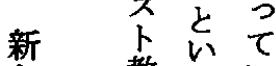
新教 5 い な に自索 展学已実 望抑務<smiles>[CH]1[CH]CC1</smiles>
辛<smiles>[CH]</smiles>
又 人 w 現市正常 実然重 識 義等要 再它古加 不。向 な む 5 な で知 知 あ 恵 恵 る。恵 他 ま 世場 俗合 社 8 会 あ 々 る の 共 之 存を の 認 課ぬ 題 る 
基 < 間

盤団をこ

と体結 の

す形び 結

る成つ論

共浽注

同対、私

体て亦充

健相老

全綮亞批

を判上

判立をう

断場可な

で か 能帰

きらに結

るそすに

このる 導

と健 実

に全 践

なさ的 二

るのな ।

か 判視 バ

占断座 !

あで提掠

るき示渒

ま他る㤵

た方。示

$コ$ は さ

モモなモ

ンンらン

セセキセ

ン

ス ス

は \&

世自教 の

俗 ら は親

性 の、和

基 コ性

強準モは

要にン

しょセ異

なりン質

い、スな

た綮に共

め示基 同
と的は へ加聖こ

公な\&しとる38化の

共部古か力。の発

性分万\&点 つ問言

をまんこをま題忧

結確でのれ移りだ衆

保変こはし彼加目 ひ

ᄂ革と戦、注学

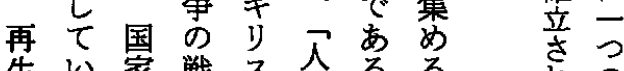

生々家戦不間るるる杂の

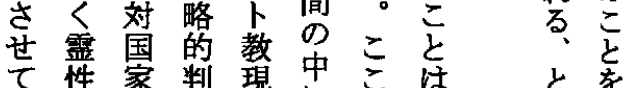

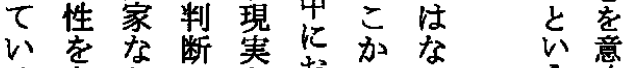

く考とに主お方少味

社光の関義い:。兄し

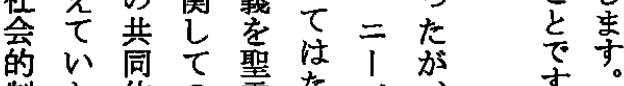

制た体の䨗たバ

度と的議論ら実

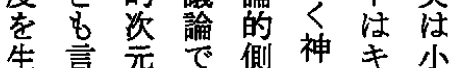

み劣にあ面の少さ

出友る加力长

す。占加ら箸通

\& = ら根兄教少義善

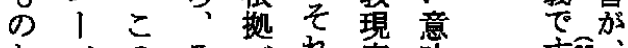

とバのそぶれ実味

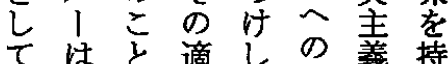

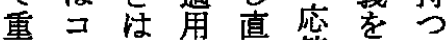

視 モ個籁 そ答聖 \&

守ン人囲亏と花の

るセ生はとしので

のン活昆て問あ

でスの常たの題っ

あを次生の利とた

る。究を活で导充利

極超扔るの考尖

的光计。抑 $え$ 心

でて制るの

は政 個浽抑

な治人、至制

$<$ の 50

文自聖た柱

花制花こ

自制努 次

由度力元分に
これ

れ注

が

現 共

寸

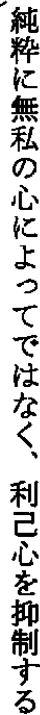




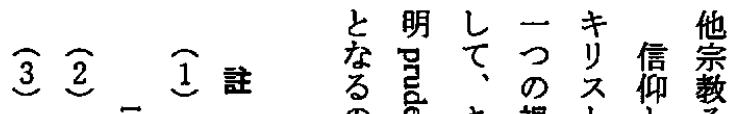

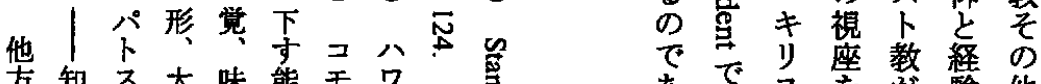

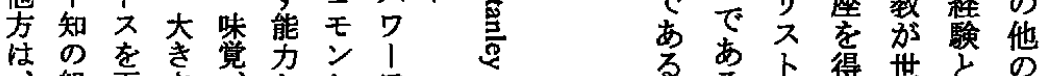

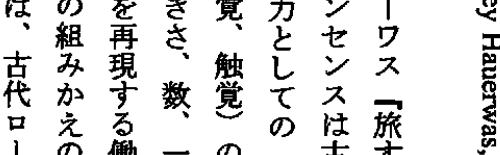
、の働一の間共卉る をめを統の通よ神焉 起にしこ識感品の 蛋

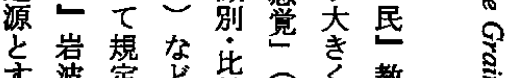

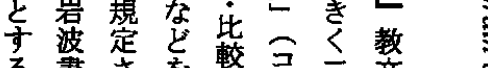

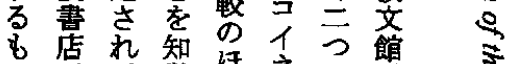

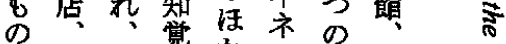

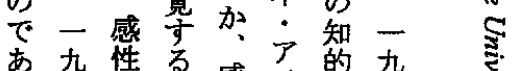
る艺艺顑不采九 的九

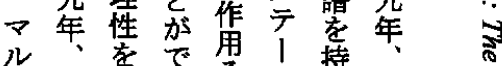

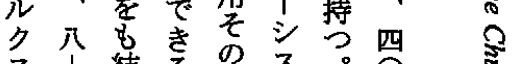

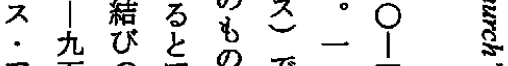
ア頁つ矛索でつ四 ウ ウ のテさ共 のととさ通上 公注賞レ 公捉理個注 の共蟹感異を起 そ势る賞な越 を多加箇し 理虫村艺等感五 る 雄想占筧感 心郎华な視竟 之通通動聴 言咸煘静賞判

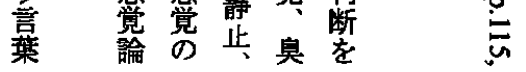

る教 得世俗 の

のこ社結加 営之会合な をみにまをる 耐をなた紏団 立開っ等弾体 さくた他守で る。宗㢇宗竅る

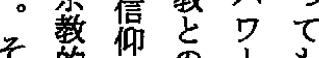
そ 的謙共絮

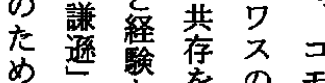
と究果問

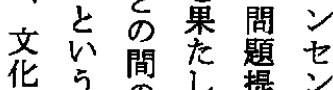
形霹吕な起 ス 成性疅加注の

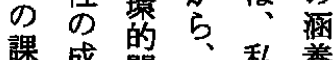
課成関、私養

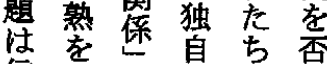
信促はのに定 にゆ神自三な 違学と公心相 感、前共思体 を信 提性 想之 も仰をののは た的共枠再協 らで有組 検 慟 しあしを討可 つるな構を能 つ筑促に も炎畋守しな 信異る、劣。 仰释他文そ 的験者花 な的と形結 営にに成果 
9 $\widehat{8} \quad \widehat{3} \widehat{6} \quad \widehat{5} \quad \widehat{4}$

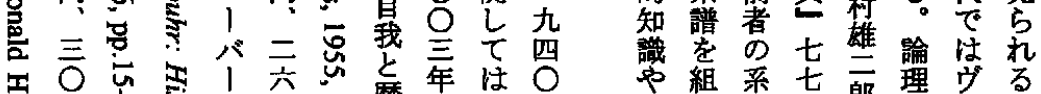

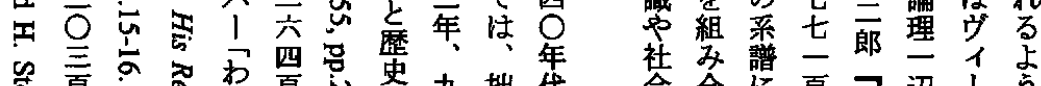

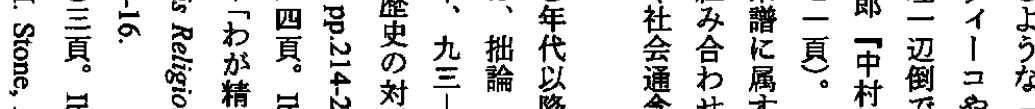

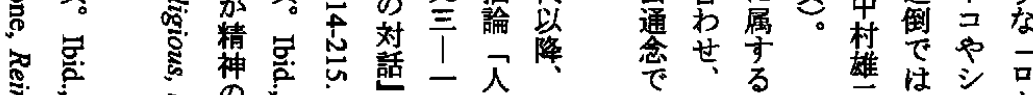

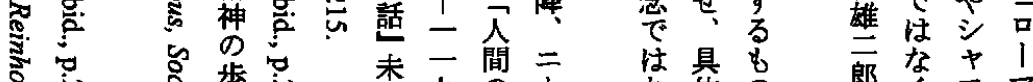

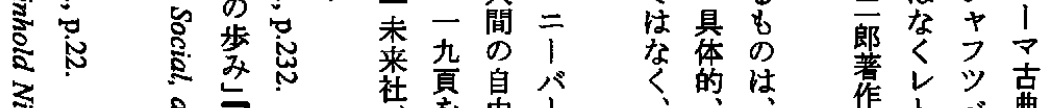

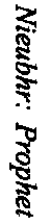

政

自

社頁自バ

2

莪

o

을

磿

史

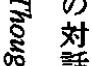

高

总 来

g 䄍

总窟

总

罍

蛋

유

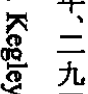

马

攵

高

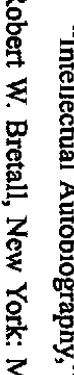

ปั่

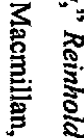

一参との

九照之関

六。の忍

四限吕

年界 界

く的 は

自 総記

由 合 憶 卢的

公な菱

共感術

西

四舀復断帛

頁 ン

木的

容少会

再 吕悉

生 L

㔖! 会

专 称

等

世コ等

るモる

はン す

たセの

的自

当蜸

加を慮

计を想理户

多㤦定解公

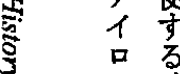

त्.

云 政

杂志

焦戈的

总早間

$\xi$

获

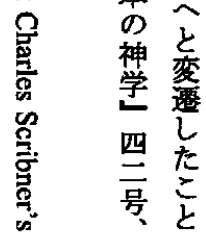

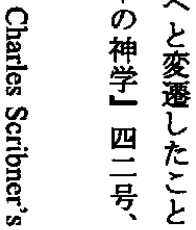

心彼法

る。㹂

点

にモな

意七方

意

払希

必単

要なは

加る两

あ儀者

集 ト

V

共甬よル

感まつ竞

觉た復ン

崖理権

波性さ人

畫方た主

一 の

九京系

九 な譜譜

年、経お市

一験心る。

三的てこ

兑知势

頁惠レは

丸と怗

山七文

高の主

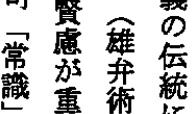

崇視㧤

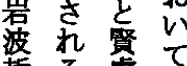

授る慮継

学の架簐

思あ想るさ 
16

$$
\widehat{15} \widehat{14} \widehat{13} \widehat{12} \widehat{11}
$$

10

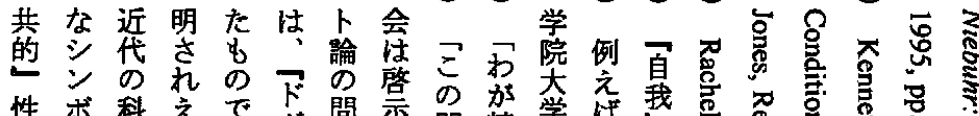

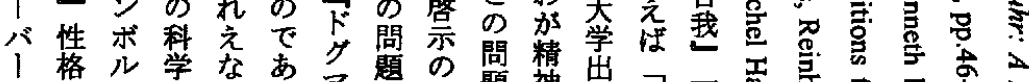

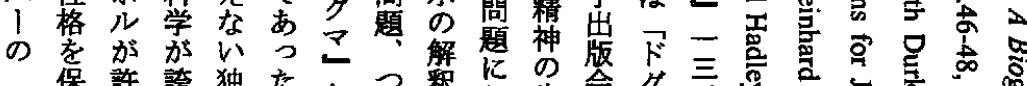

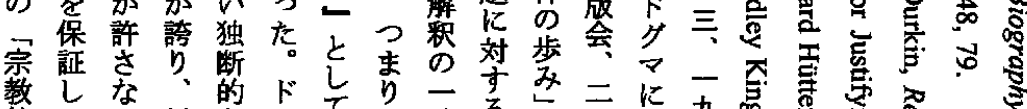

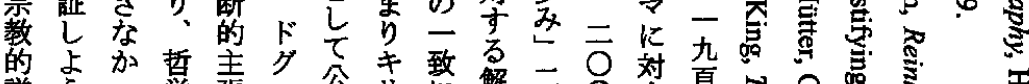

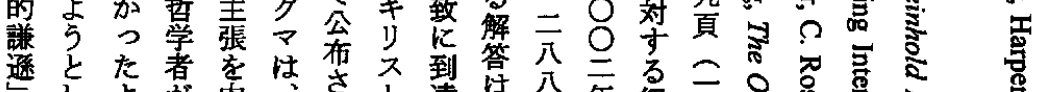

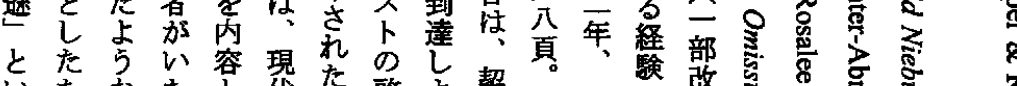

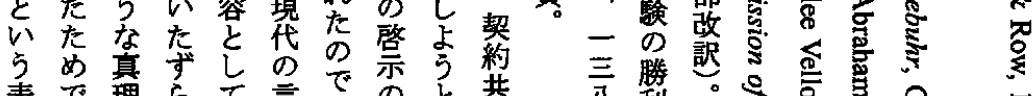

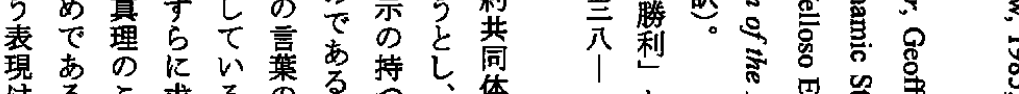

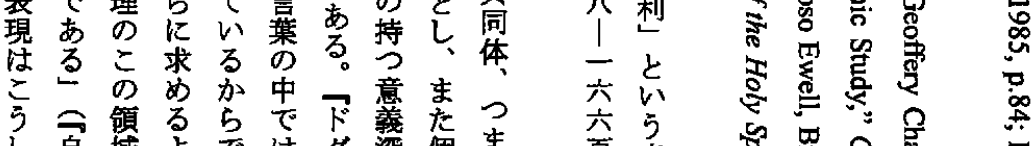

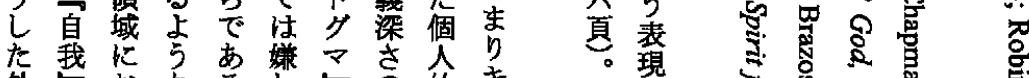

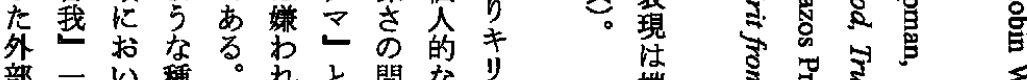
部一心種。れと問なり と咞て類奏る公題幻

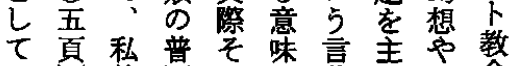
の官的遍のを菜炕空会 他解要上持番取想の 者楥当 表性飞文口报持威 受独索占1 容断 5 グにマた気 5 守性与 古な帝何禾占 る竞在国竞

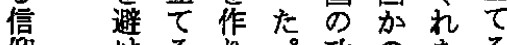
仰けるり。政のをる 加上落教防

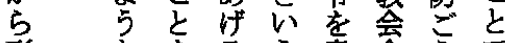
形飞索意会で

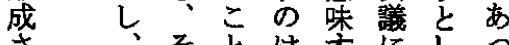

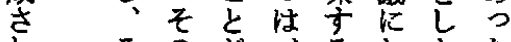

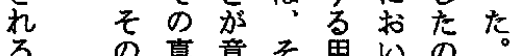
霔真理罳机語てでそ 性理のさは例一あし

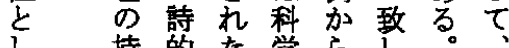

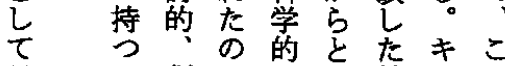

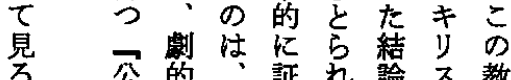

端

经

彼

唯

姿

勢

表

七

r

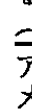

劣

为

史

厂

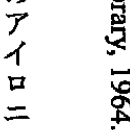

I

聖 蛋喜范

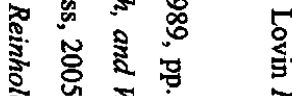

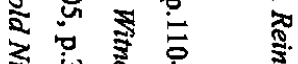

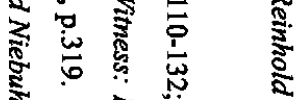

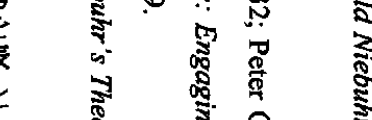

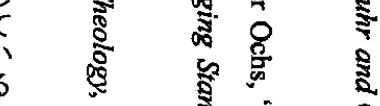

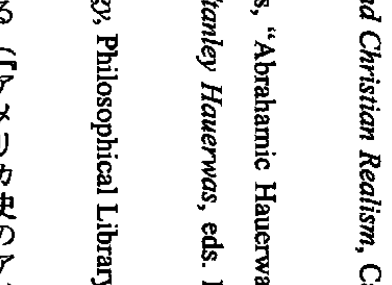


論 文

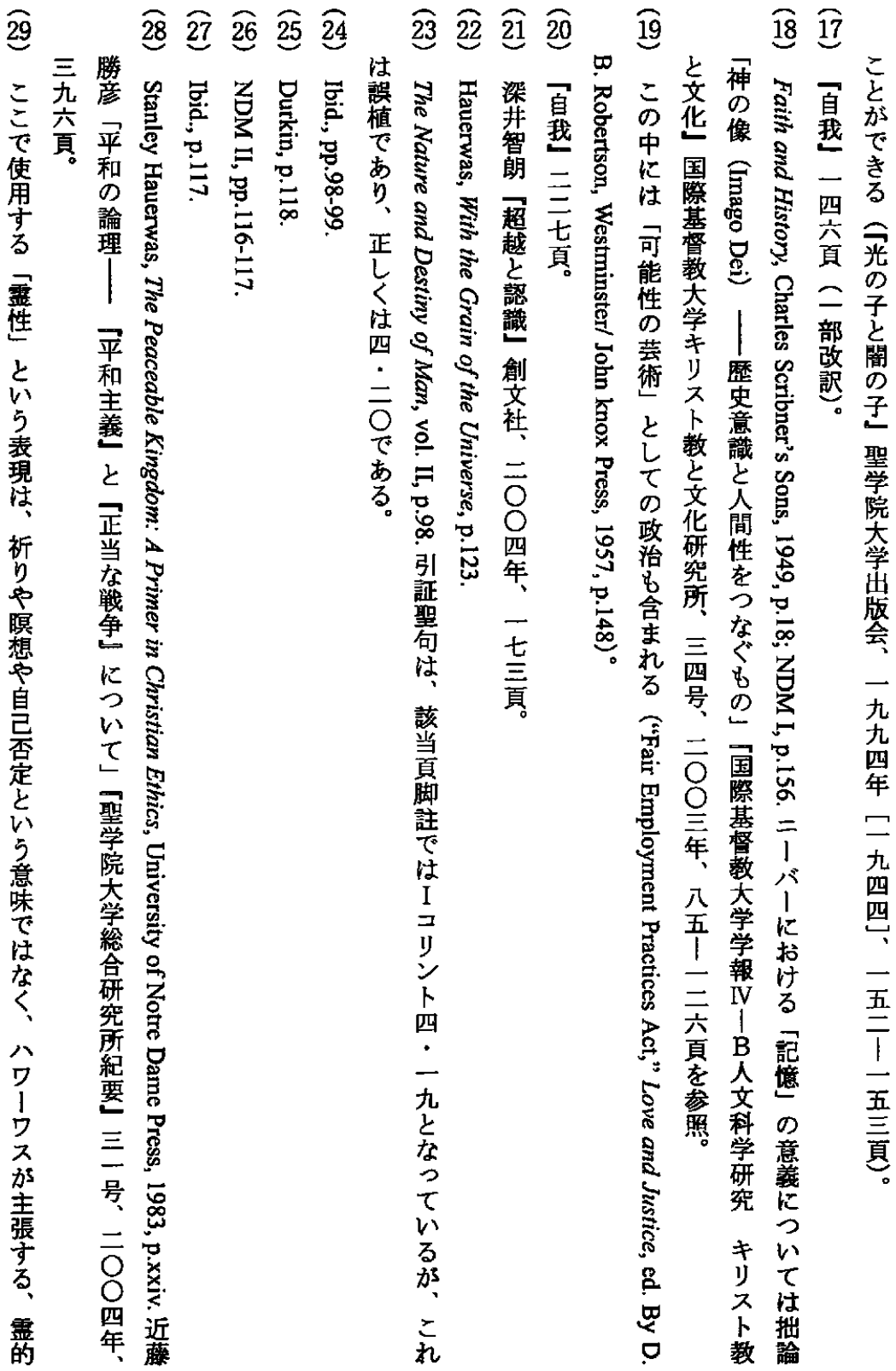


$\widehat{36} \widehat{35} \widehat{34} \widehat{33}$

$\widehat{32}$

31 $\widehat{30}$

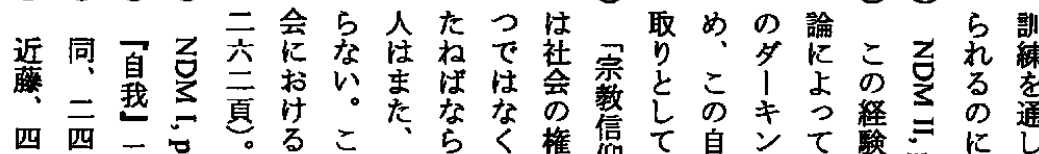

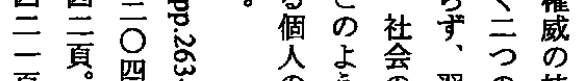
耍

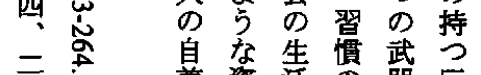

$$
\begin{aligned}
& \text { 署 }
\end{aligned}
$$

自等告惯武号

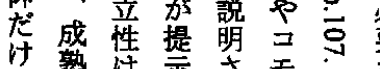

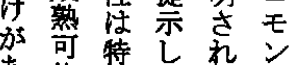

永占

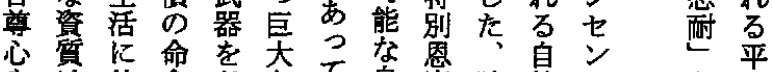

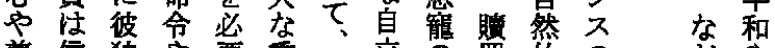

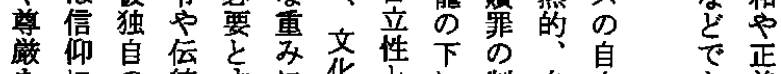

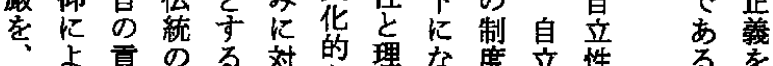

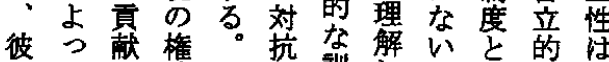

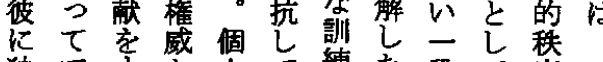

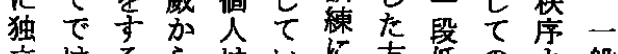

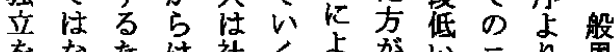

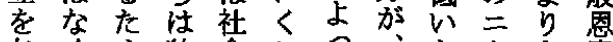

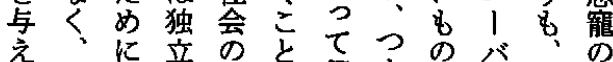

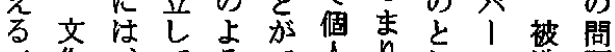

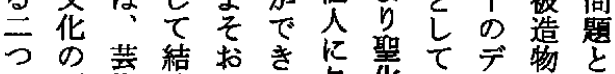

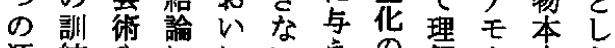

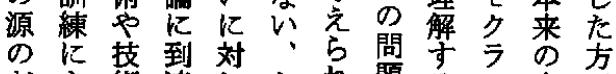

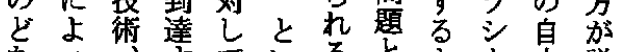

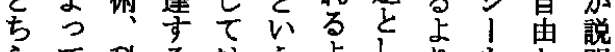

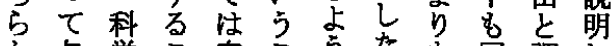

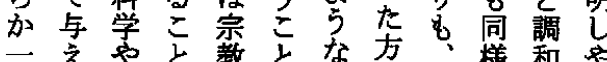

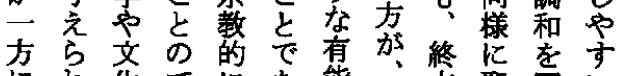

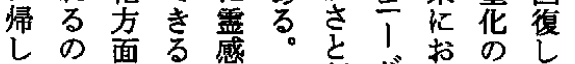

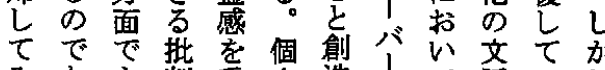

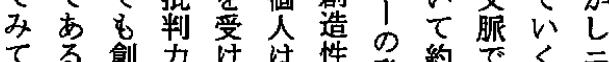

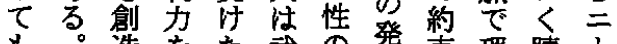

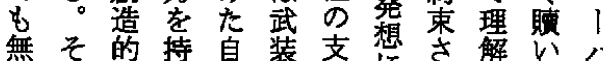

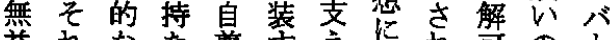

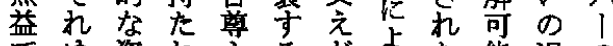

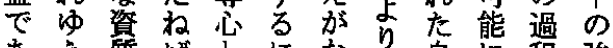

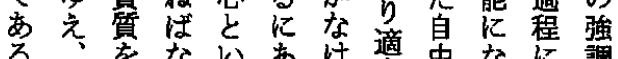

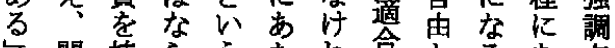

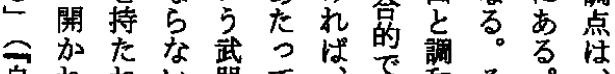

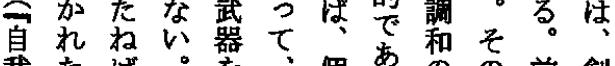

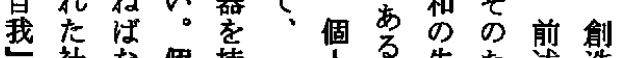

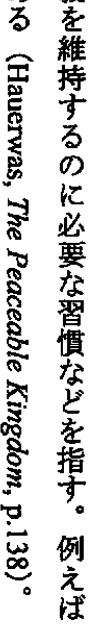

暴

㲾

直

面

ᄂ

覆 


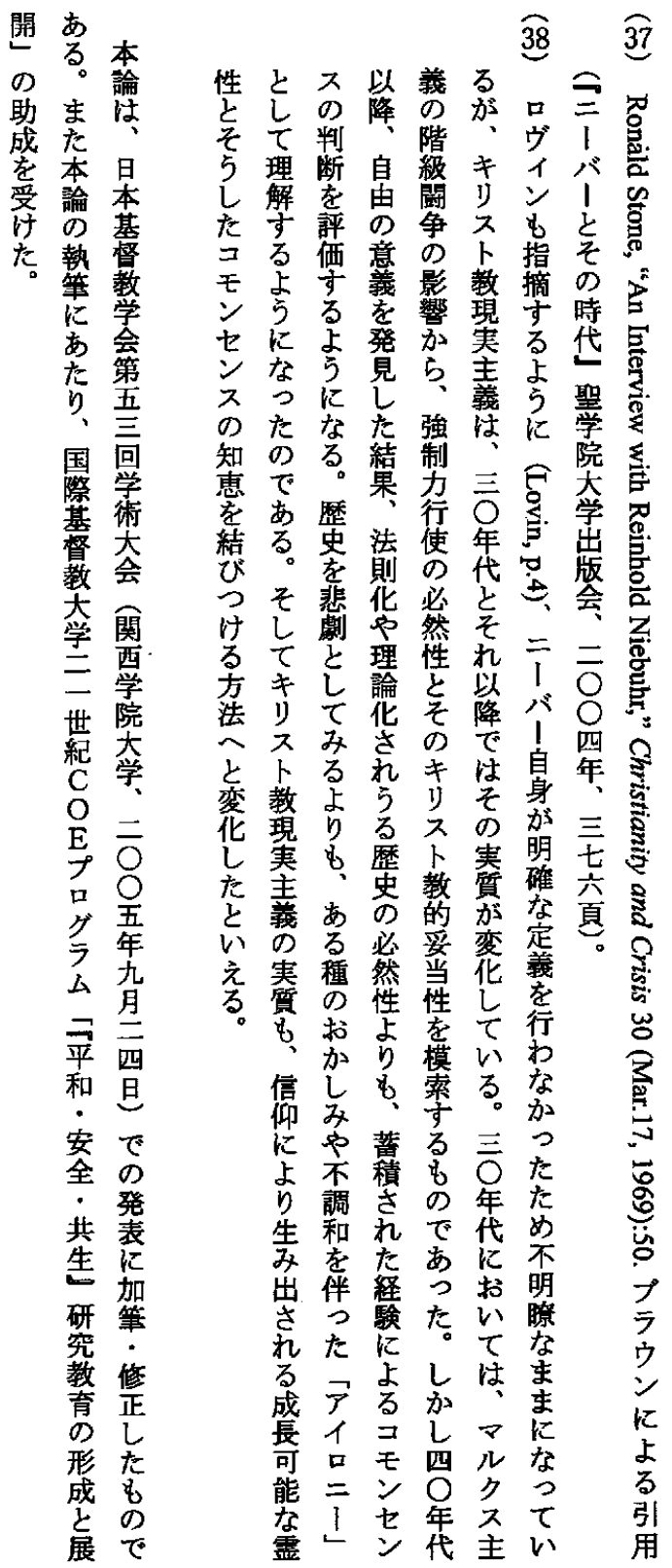

